\title{
Carbon footprint of milk production in Brazil: a comparative case study
}

\author{
Cristiane Maria de Léis - Edivan Cherubini - Clandio Favarini Ruviaro • \\ Vamilson Prudêncio da Silva • Vinícius do Nascimento Lampert • \\ Airton Spies • Sebastião Roberto Soares
}

Received: 3 June 2013 / Accepted: 17 October 2014 / Published online: 29 October 2014

(C) Springer-Verlag Berlin Heidelberg 2014

\begin{abstract}
Purpose Livestock production is a recognized source of environmental impact, and this sector indirectly involves approximately 5 million people in Brazil. Livestock production includes nearly 1.5 million milk producers that use several different production systems. We chose the southern region of Brazil to evaluate the carbon footprint (CF) per $1 \mathrm{~kg}$ of energy-corrected milk (ECM) at the farm gate for different dairy production systems with the use of a good level of technology.

Methods The dairy production systems were confined feedlot system, semi-confined feedlot system (including some grazing), and pasture-based grazing system. A sensitivity analysis of the dry matter intake (DMI) in each farming system and an uncertainty analysis based on a Monte Carlo (MC) simulation were performed to complement the discussion. The standards ISO 14040: 2006 and ISO 14044: 2006 were used for the comparative life cycle assessment (LCA) focused on the CF. The LCA software tool SimaPro 7.3.3 was used. Sensitivity analyses were
\end{abstract}

Responsible editor: Nydia Suppen-Reynaga

C. M. de Léis $(\varangle) \cdot$ E. Cherubini $\cdot$ V. Prudêncio da Silva

S. R. Soares

Life Cycle Assessment Research Group (Ciclog), Universidade

Federal de Santa Catarina, Campus Trindade, Caixa Postal 476,

Florianópolis, SC 88040-970, Brazil

e-mail: cristianeleis@gmail.com

C. F. Ruviaro

Universidade Federal da Grande Dourados, UFGD/FACE,

Dourados, Brazil

V. do Nascimento Lampert

Brazilian Agricultural Research Corporation, EMBRAPA- CPPSUL,

Bagé, Brazil

V. Prudêncio da Silva $\cdot$ A. Spies

EPAGRI/CEPA, Rod. Admar Gonzaga, 1347,

Florianópolis 88034901, Brazil conducted on input data for total digestible nutrients (TDN) and crude protein (CP) based on values from the literature.

Results and discussion The comparative LCA showed that the confined feedlot system had a lower CF than the other systems studied. Total greenhouse gas emissions were $0.535 \mathrm{~kg} \mathrm{CO}_{2} \mathrm{e} \mathrm{kg} \mathrm{ECM}^{-1}$ for the confined feedlot system, $0.778 \mathrm{~kg} \mathrm{CO}_{2} \mathrm{e} \mathrm{kg} \mathrm{ECM}{ }^{-1}$ for the semi-confined feedlot system, and $0.738 \mathrm{~kg} \mathrm{CO}_{2} \mathrm{e} \mathrm{kg} \mathrm{ECM}^{-1}$ for the pasture-based system without considering the impact from direct land use change (dLUC). When considering these emissions, the CFs for grain and cottonseed production showed $\mathrm{CF}$ increases of 45.0,36.9, and $37.3 \%$ for the confined feedlot, semi-confined feedlot, and pasture-based systems, respectively. The results from the MC simulations showed low uncertainty through variations in TDN and $\mathrm{CP}$. The coefficient of variation was $1.1 \%$ for the confined feedlot, $0.7 \%$ for the semi-confined feedlot, and $1.0 \%$ for the pasture systems.

Conclusions The uncertainties were due mainly to variations in $\mathrm{N}_{2} \mathrm{O}$ emissions from manure for the three systems. The $\mathrm{CF}$ in Brazilian systems was lower than almost all the results found in the literature, even when impacts from the dLUC were considered. The lowest $\mathrm{CF}$ in this case study was due mainly to the emission factor used for enteric fermentation.

Keywords Brazilian milk production · Carbon footprint . Confined feedlot system $\cdot$ Direct land use change $\cdot$ Life cycle assessment $\cdot$ Pasture system $\cdot$ Semi-confined feedlot system

\section{Introduction}

The world demand of food products is continuously increasing, driven by urbanization and economic and population growth (Notarnicola et al. 2012; Roy et al. 2009; Steinfeld et al. 2006), and consequently the impacts on climate change, changes in soil quality and water, and biodiversity losses 
increase as well. The livestock sector is responsible for $18 \%$ of global greenhouse gas (GHG) emissions (FAO 2013a, b; Steinfeld et al. 2006) which highlight the importance of this activity to reduce the environmental impact on climate change. Therefore, the concern for sustainable food production has driven to an increase of research on environmental sustainability of food production and distribution systems (Cederberg and Mattsson 2000; Flysjö et al. 2011a; Guinée et al. 2002; Roy et al. 2009; Ruviaro et al. 2012). Questions concerning what type of food production system, including technology choices, represent the best environmental performance, in relation to the amount of production and the total GHG emitted in each different region, have become more frequent, and dairy products are no exception (Del Prado et al. 2013; Flysjö et al. 2011a, b; González-Garcia et al. 2013; Iribarren et al. 2011).

According to FAO (2010), in 2007, the dairy sector was responsible for $4 \%$ of global GHG in which the overall contribution of the global milk production was estimated at $2.7 \%$. These emissions can occur directly through animal rearing and grazing or indirectly as the expansion of grains production for animal feed, replacing forests, and reducing natural habitats (FAO 2013a; Steinfeld et al. 2006) for agricultural areas.

The GHG emissions from the dairy industry are directly affected by different means of animal production (beef and milk) and by the effects of the dairy industry on forage and range productivity, as well as on feed intake and feed conversion rates (Gerosa and Skoet 2012). Besides, as with other animal products, the dairy industry has undergone technological changes to meet growing demand (Gerosa and Skoet 2012).

Several life cycle assessment (LCA) of dairy production systems have been performed in many parts of the world (Basset-Mens et al. 2009b; Bonesmo et al. 2013; Castanheira et al. 2010; Henriksson et al. 2011; Iribarren et al. 2011; Kristensen et al. 2011; Thomassen et al. 2009; Yan et al. 2011). The life cycle assessment (LCA) methodology can help identify opportunities for improving environmental performance at several points in this life cycle. LCA serves to compile and assess the total environmental impacts (e.g., contribution to climate change, eutrophication, acidification, land use, etc.) and resource used and emissions from the entire life cycle of a product or service (ISO 2006a; b). On the other hand, the carbon footprint (CF) only accounts to emissions with climate change potential (i.e., GHG emissions). Nevertheless, the $\mathrm{CF}$ has received most of the current attention among different environmental impact categories in LCA (Flysjö et al. 2011a; Wiedmann and Minx 2008) due to several factors, including agricultural intensification. Several methodologies have been developed to calculate the CF of products, for instance, the PAS2050 (BSI 2008), the
GHG protocol (WRI WBCSD 2011), IPCC (2006c), FAO (2010), and IDF (2010b). The latter two are specific for dairy products. According to IDF (2010b), all these methodologies are based on the ISO standards (ISO 2006a; b; 2013). There are some differences among these methodologies, for instance, the proposition of which allocation method and whether or not to account for biogenic carbon emissions.

Although the dairy industry has recently been studied, there is still a lack of information regarding the net emissions from dairy farms and the consequences of variations in applied technology and production systems used (Flysjö et al. 2011a; Rotz et al. 2010). On top of that, in large countries (e.g., USA and Brazil), the systems can be different from one state to another, due to the technology choices, feed intake, and feed conversion rates, etc., varying also their environmental impacts (IDF 2009).

A research on milk production in South America (Bartl et al. 2011) evaluated two small milk production systems in Peru. This research showed that the global warming potential, acidification, and eutrophication were higher for $1 \mathrm{~kg}$ energy-corrected milk (ECM) produced in the highlands than for that produced at the coast. The dairy production sector will certainly demand more research to create an inventory of animal GHG emissions applicable to tropical and subtropical regions, such other countries of Latin America as Brazil (Bartl et al. 2011; Ruviaro et al. 2012; Spies 2003).

In Brazil, the application of the LCA methodology and $\mathrm{CF}$ to the agribusiness sector is still in its infancy (Ruviaro et al. 2012). Currently, no environmental information using LCA is available regarding Brazilian milk production, and the consumption of milk increased in recent years. Brazilian LCAs represent an important step in reaching a more sustainable livestock production system and to avoiding deforestation of new areas.

The goal of this study was therefore to assess the CF per $1 \mathrm{~kg}$ of energy-corrected milk at the farm gate for different dairy production systems in the southern region of Brazil: a confined feedlot system, a semi-confined feedlot system (including some grazing), and a pasturebased grazing system with the use of a good level of milk production technology. These dairy production systems do not use imported feed. These farms are not representative of the majority of dairy farms in Brazil but represent those with better performance about $3.0 \%$ based on ECM (Zoccal et al. 2012). A sensitivity analysis of the dry matter intake (DMI) at each farm and an uncertainty analysis based on Monte Carlo (MC) simulation were performed to complement the discussion of the $\mathrm{CF}$ of the Brazilian dairy industry. The results considered impacts with and without direct land use change (dLUC) for the three dairy farms studied. 


\subsection{Brazilian dairy farms}

Livestock production in Brazil indirectly involves approximately 5 million people, with almost 1.5 million milk producers (Carvalho et al. 2003; Stock and Carneiro 2010). Brazilian dairy production represents approximately $4.8 \%$ of the worldwide production (IDF 2010a).

Considering the size of the country and the range of climate and soil conditions, the territory of Brazil allows the adaptation and variation of activities according to regional requirements, with differences in farm structure and production intensity. As a result, several different milk production systems can be observed (Marques 2003; Massuda et al. 2010; Zoccal et al. 2012). The variety in milk production systems makes it difficult to characterize the industry as a whole. For example, with regard to dairy cattle feed, the perpetual variation in the quantities offered due to their quality and cost of acquisition or production can be reflected in the great variation in daily nutrient intake.

Some producers still use rudimentary techniques, while others can be compared to the world's most competitive farms with a high-technology level (Massuda et al. 2010; Zoccal et al. 2012). According to Primavesi et al. (2012), the Brazilian milk production system most commonly used is the pasture-based system, with only $2.4 \%$ of the milk produced using the confined feedlot system.

A large number of farms have low production, even though they are largely responsible for the milk consumed in Brazil. Approximately $80.0 \%$ of the farms produce less than $51 \mathrm{~kg} \mathrm{ECM} \mathrm{day}{ }^{-1}$ per farm and contribute $26.0 \%$ of the total amount of production, while $17.0 \%$ of the farms produce between 51 and $202 \mathrm{~kg} \mathrm{ECM} \mathrm{day}^{-1}$ and account for $39.0 \%$ of the production. Only $3.0 \%$ of the dairy farms produce more than $202 \mathrm{~kg} \mathrm{ECM} \mathrm{day}{ }^{-1}$ in each farm, contributing $35.0 \%$ of Brazilian milk production (Zoccal et al. 2012).

According to IBGE (2011), the southern region of Brazil is the major milk producer with $32.0 \%$ of the total production in the country (more than 32 billion liters in 2011). This region has great potential for the intensification of animal production based on pasture due to the possibility of exploiting the productive potential of tropical perennial grasses and annual forage, such as millet, sorghum, sunn hemp, and pigeon pea, in the period from autumn to spring. In addition to tropical forage, the weather conditions also allow the production of high-quality annual grasses and temperate winter legumes, such as oats, rye, triticale, peas, and vetch (Oliveira 2002).

\section{Methods}

The method used for the comparative evaluation is a life cycle assessment focused on the $\mathrm{CF}$ for different Brazilian milk production systems. The LCA was performed following the standardization (ISO 2006a; b) based on primary data and secondary data from Ecoinvent ${ }^{\circledR}$ and from specialized literature. The LCA software tool SimaPro 7.3.3 was used for computing the product $\mathrm{CF}$.

The choice of these farms was supported by the Santa Catarina State Agricultural Research and Rural Extension Enterprise (EPAGRI) and the State Deputy Secretary for Agriculture and Fisheries of Santa Catarina, which are reference institutions for livestock in Santa Catarina State. The Center for Multidisciplinary Studies of Dairy Cattle of the State University of Maringá (UEM) also has extensive experience with dairy cattle. These institutions have found in several studies a wide variability of dairy systems in Brazil, but both institutions pointing out that the three selected farms represent very well the three most common systems (feedlot, semi-confined feedlot, and pasture-based grazing) in their respective regions taking into account the historical milk production database.

Monte Carlo (MC) analysis was used to evaluate the influence that variations in feed diet have on the CF of the dairy systems used in Brazil. According to Basset-Mens et al. (2009a), the identification of the key parameters responsible for the uncertainty in the analysis is important and is a challenging issue.

\subsection{Production systems}

The farms that represent a confined feedlot system, a semiconfined feedlot system (including grazing), and a pasturebased grazing system are located in Southern Brazil, more specifically, in Parana and Santa Catarina states (Fig. 1). For confined and semi-confined feedlot systems, the cow breed was Holstein, while for pasture-based grazing system, the cow breed were Holstein and Jersey.

The dairy farm that represents the confined feedlot system is located in Mandaguari City, in north-central Parana state, which is characterized by a tropical climate (Koeppen 1948). The annual average temperature is below $20^{\circ} \mathrm{C}$. The total area of this farm is 48 ha, although only 17 ha are used for dairy production. This farm has a herd of 55 animals (including calves, heifers, dry cows, and lactation cows), and the animals receive $100.0 \%$ of their food from a trough. The ECM produced in this system is $7667 \mathrm{~kg} \mathrm{ECM} \mathrm{cow}^{-1}$ year $^{-1}$ (to lactation period of 305 days). The diet is rich in silage, commercial feed concentrate (cottonseeds, corn grains, wheat bran, soybean hulls, premix), hay, minerals, premix, and other cattle foodstuffs. The variation in the diet depends on price and season. Based on the diet feed (see Table 1), the annual feed intake as dry matter (DMI) per cow was estimated as $6335 \mathrm{~kg}$ for the confined system (to lactation period), and the feed conversion efficiency (FCE) was $1.2 \mathrm{~kg} \mathrm{ECM} \mathrm{kg} \mathrm{DMI}^{-1}$. In this scenario, we considered the manure management 
Fig. 1 Dairy farm locations $(1-$ confined feedlot system; 2semi-confined feedlot system; 3 - pasture system)

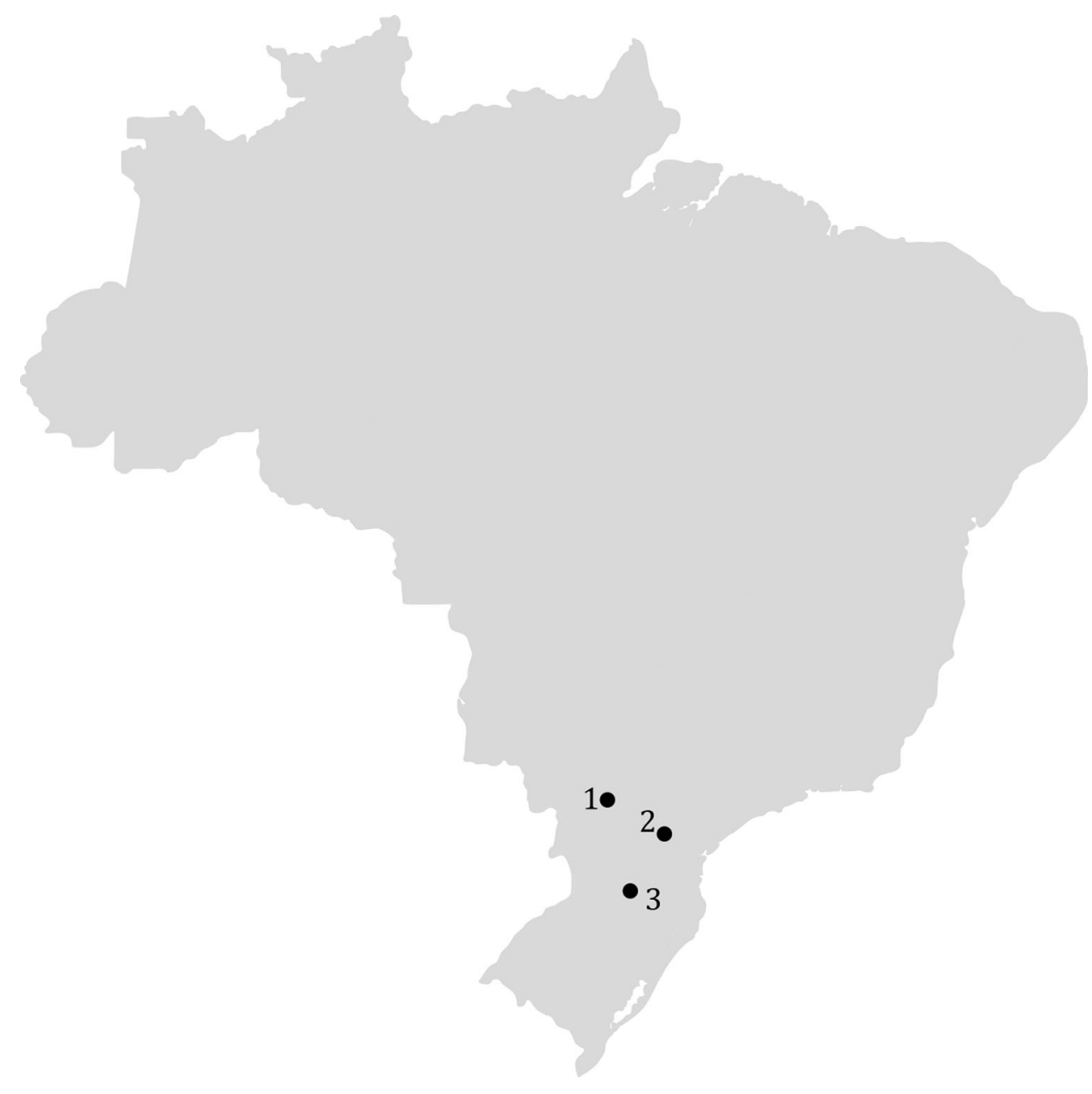

system (MMS) as a dry lot, and the emissions of the manure management system were calculated following the IPCC (2006a).

The semi-confined feedlot farm is located in Porto Amazonas City, in the metropolitan area of Curitiba, Parana State, and can be characterized as an intensive system in which the animals are confined with some grazing. This farm has a herd of 137 animals (including calves, heifers, dry cows, and lactation cows). The average yearly milk production is approximately $7324 \mathrm{~kg}$ ECM per cow (to lactation period). The feed is rich in silage, citrus pulp (byproduct of the orange juice industry), brewers spent grain (byproduct of the beer industry), commercial feed concentrate (cottonseeds, corn grains, wheat bran, soybean hulls, premix), minerals, premix, forage, and other cattle foodstuffs. At this farm, the diet of the cattle may also vary according to price and seasonal variations. The annual feed intake as the DMI per cow was estimated as $5628 \mathrm{~kg}$, and the $\mathrm{FCE}$ was $1.3 \mathrm{~kg} \mathrm{ECM} \mathrm{kg} \mathrm{DMI}{ }^{-1}$ (to lactation period). Manure is stored in outdoor slurry tanks with a natural crust cover and then spread on the soil.
The pasture-based system is located in Campos Novos City in the midwest region of Santa Catarina State. In this system, $100.0 \%$ of the animals are fed by grazing and receive a small amount of concentrated feed after milking. The herd is composed of 268 animals (including calves, heifers, dry cows, and lactation cows), and the milk production is $5305 \mathrm{~kg}$ ECM cow ${ }^{-1}$ year $^{-1}$ (to lactation period). The diet is rich in pasture and is composed mainly of oats and rye grass in the winter. During other seasons, the diet comprises other types of forage, such as corn silage. The concentrated feed is made on the farm and is composed of corn, soybean meal, and mineral salts, with an annual feed intake as the DMI per cow of approximately $4657 \mathrm{~kg}$ and an FCE of $1.1 \mathrm{~kg}$ ECM kg DMI ${ }^{-1}$. The pasture system uses swine manure as organic fertilizer in pasture and for forage. The cattle manure in this system remains in the grazing area.

According to Prudêncio da Silva et al. (2010), in Southern Brazil, the natural forest is not part of the Amazon biome (rainforest) and was deforested a long time ago. The area is considered a consolidated area, so the impacts from deforestation should be considered only for grains produced in 
Table 1 Variations in TDN, CP, DMI, and GE in the animal diet for the systems studied

\begin{tabular}{|c|c|c|c|c|c|c|c|c|}
\hline \multirow[t]{3}{*}{ Diet in each dairy system ${ }^{a}$} & \multicolumn{3}{|l|}{ TDN } & \multicolumn{3}{|l|}{$\mathrm{CP}$} & \multirow{3}{*}{ 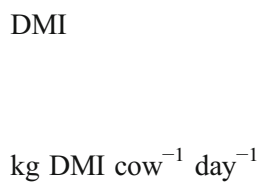 } & \multirow{3}{*}{$\begin{array}{l}\mathrm{GE}^{\mathrm{c}} \\
\mathrm{kcal} \mathrm{kg}^{-1}\end{array}$} \\
\hline & \multicolumn{3}{|l|}{$(\%)$} & \multicolumn{3}{|l|}{$(\%)$} & & \\
\hline & Min. & Mean & Max. & Min. & Mean & Max. & & \\
\hline \multicolumn{9}{|l|}{ Confined feedlot system } \\
\hline Concentrated feed & 78.86 & 80.66 & 82.29 & 17.39 & 18.33 & 19.45 & 6.44 & 4.450 \\
\hline Corn silage & 59.18 & 61.66 & 63.97 & 7.44 & 8.03 & 8.75 & 12.46 & 4.645 \\
\hline Cottonseeds & 77.00 & 80.00 & 82.00 & 12.23 & 13.79 & 15.31 & 0.01 & 5.650 \\
\hline Maize germ & 78.00 & 81.00 & 84.00 & 10.28 & 11.57 & 13.19 & 1.06 & 4.030 \\
\hline Soybean meal & 78.86 & 80.66 & 82.29 & 45.63 & 47.00 & 48.37 & 0.62 & 4.434 \\
\hline \multicolumn{9}{|l|}{ Semi-confined feedlot system } \\
\hline Brewers spent grain ${ }^{\mathrm{b}}$ & 58.05 & 60.39 & 62.84 & 11.02 & 11.90 & 12.73 & 2.31 & 3.700 \\
\hline Citrus pulp & 75.52 & 78.60 & 81.06 & 6.56 & 6.90 & 7.24 & 1.92 & 3.920 \\
\hline Concentrated feed & 78.41 & 81.33 & 83.90 & 10.28 & 11.57 & 13.19 & 3.84 & 4.450 \\
\hline Corn silage & 59.18 & 61.66 & 63.97 & 7.44 & 8.03 & 8.75 & 7.69 & 4.645 \\
\hline Pasture & 65.26 & 68.00 & 70.73 & 8.80 & 9.83 & 11.27 & 2.31 & 3.759 \\
\hline \multicolumn{9}{|l|}{ Pasture system } \\
\hline Concentrated feed (maize) & 73.16 & 76.00 & 79.35 & 8.06 & 8.63 & 9.22 & 2.82 & 4.545 \\
\hline Concentrated feed (soybean meal) & 78.86 & 80.66 & 82.29 & 45.6 & 47.0 & 48.4 & 0.99 & 4.434 \\
\hline Corn silage & 59.18 & 61.66 & 63.97 & 7.44 & 8.03 & 8.75 & 4.42 & 4.645 \\
\hline Hay (oat and ryegrass) & 53.02 & 55.33 & 57.81 & 10.16 & 11.23 & 12.43 & 1.99 & 4.380 \\
\hline Pasture & 66.02 & 68.33 & 70.81 & 15.63 & 17.00 & 18.37 & 5.05 & 3.750 \\
\hline
\end{tabular}

${ }^{a}$ These diets are specific to each dairy farm studied according to the producer

${ }^{\mathrm{b}}$ By-product of the beer industry

${ }^{\mathrm{c}}$ According by NRC (2001); Peripolli et al. (2011); Valadares Filho et al. (2011)

central-west Brazil. Because the farms studied consume grains from Southern Brazil, the systems were assessed without considering emissions related to direct land use change (dLUC).

Several authors (Cederberg et al. 2011; FAO 2010; Flysjö et al. 2011a; Jungbluth et al. 2007; Leip et al. 2010) have considered deforestation in the production of grains independent of Brazilian regions. We therefore considered the dLUC factors for central-west Brazil from Prudêncio da Silva et al. (2010) for the corn and soybeans produced in the south, seeking to complement the discussion of the variation in the results.

\subsection{Functional unit and allocation}

The functional unit (FU) was determined based on the mass of the product as $1 \mathrm{~kg} \mathrm{ECM}$ at the farm gate level according to the equation described by Sjaunja et al. (1990) for corrected fat and protein. Although the milk production has by-products, in this study, we did not consider allocation once we assumed the same replacement rates, meat culled cows, and meat surplus calves per cow for the three systems according to the technical patterns of dairy herd management (Campos et al. 2001; Ribeiro et al. 2003). This approach was also used by Flysjö et al. (2011a) and Henriksson et al. (2011) that did not use allocation. For this study, we did not use allocation, since the by-product meat is responsible for less than $1 \%$ of the total mass of outputs.

As the manure in Brazilian milk production is used as organic fertilizer on the farm, no allocation was needed. For soybean processing, we allocated according to the economic value of the by-products, i.e., $65.1 \%$ for soybean meal ( $€ 258.25$ per ton of soybean meal) and $34.9 \%$ for soybean oil (€576.42 per ton of soybean oil) (Alvarenga et al. 2012). For brewers spent grain, by-product of barley processing, we use mass allocation.

For the swine manure used in the pasture system, the environmental costs of organic fertilizer can be done following at least two approaches (Knudsen et al. 2010): (i) considering that the manure is a waste product, so impacts should be allocated to the meat; and (ii) considering that manure has a value as a fertilizer and the environmental costs should be accounted to this by-product. However, it is a common practice in LCA studies to consider the concept of impact avoided for swine manure (Basset-Mens and van der Werf 2005; Dalgaard 2007; Nguyen et al. 2011; Williams et al. 2006). 
Thus, we considered organic fertilizer as not free of GHG. The estimative was based on the environmental gains of manure usage as organic fertilizer in a LCA of swine production in Brazil (unpublished data) through the substitution method, these reductions in the GHG of swine meat (around $4 \%$ ) were attributed to the manure.

\subsection{System boundaries}

The system boundary for this study is characterized as from "cradle to farm gate" (Fig. 2). The dairy farm inputs considered were feed concentrate, silage, energy, fertilizer, transport, and fuels. Inputs such as construction, detergents, disinfectants, silage agents, machinery, and medicines were not considered because of the lack of data, while small volumes of feed ingredients such as vitamins were excluded by cutoff criteria that contributing less than $1 \%$ of mass (ISO 2006b).

For the transport of inputs, such as feed and supplies used on the farms, we considered the distance $(\mathrm{km})$ required for the acquisition of the products, i.e., the distance from where the producer purchased feed until the arrival of the feed at the dairy farm. For feed ingredients (cottonseeds and wheat bran), we used data from the Ecoinvent ${ }^{\circledR}$ database, NRC (2001), Peripolli et al. (2011), and Valadares Filho et al. (2011).

The energy from the public grid system distribution was considered (e.g., milk refrigeration on the farm and diesel). Brazil is considered a matrix in which the energy is $84.0 \%$ from hydropower, $1.8 \%$ from coal, and the other $14.2 \%$ from other sources (Frischknecht et al. 2007). This process of energy was used from the Ecoinvent ${ }^{\circledR}$ database.

Wastes were evaluated according to their final destination in each system following the IPCC (2006a) definitions. These dairy farms did not offer any kind of service to other farms.

\subsection{Life cycle inventory}

The data used represent an average of two agricultural seasons (the years 2008/2009 and 2009/2010) for each farm. Although with only 2 years of observation, it was considered sufficient for this study because the owners respondents confirmed little variability in food consumption per cow in recent years. The comparison was equalized by the herds of the farm for all three production systems studied, e.g., the lactation period in the farms studied was 305 days. Total milk yield up to 305 lactation days was calculated using a method officially

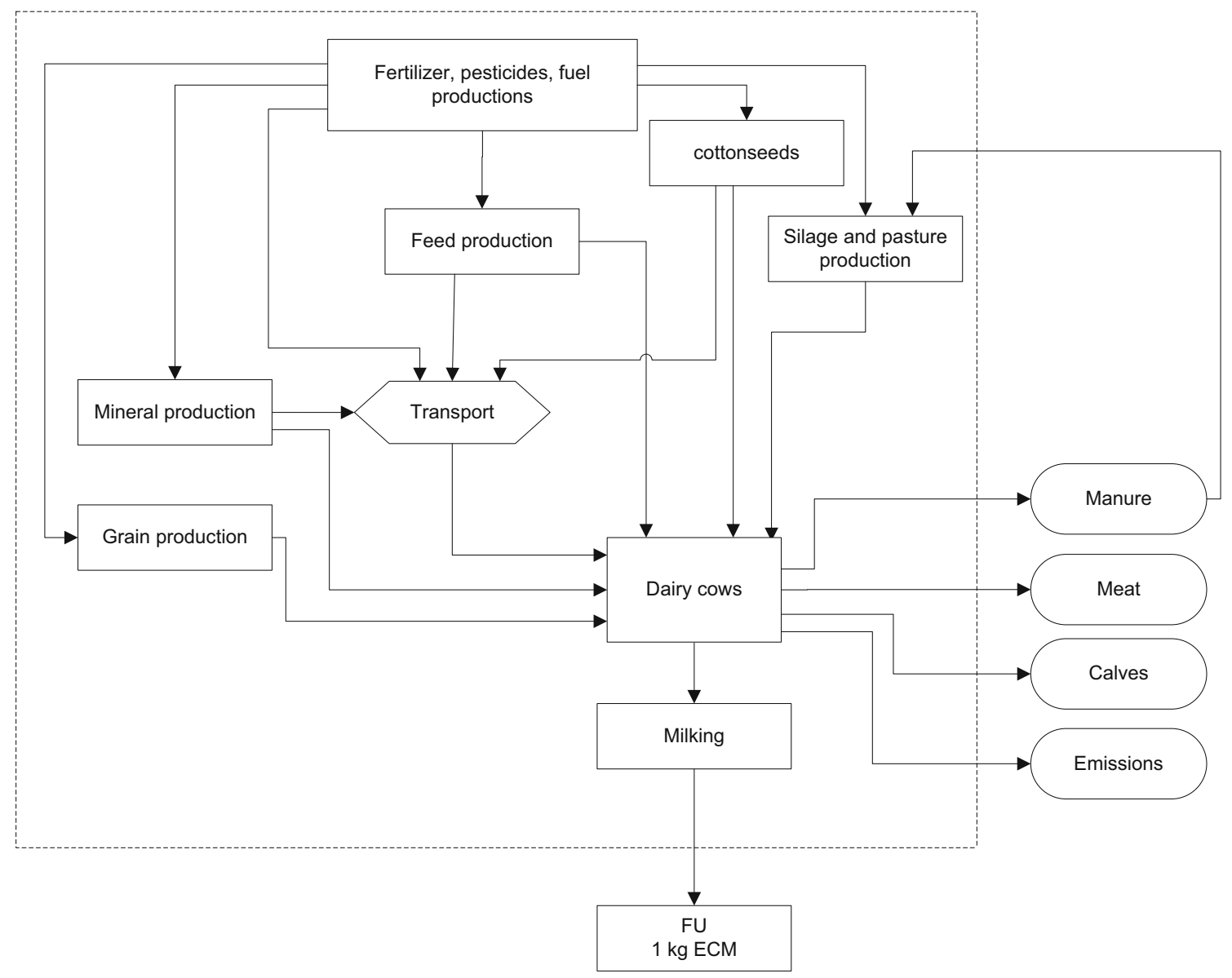

Fig. 2 System boundaries of Brazilian milk production from "cradle to farm gate" 
recognized by the Ministry of Agriculture (Brasil 1986) and this period is in accordance with the research carried out by Carvalho et al. (2003) which states that in Brazil varies from 290 to 305 days. The dairy herd consists of growing heifers, lactating cows, and non lactating cows. The dairy cow replacement rate is approximately $25.0 \%$ (Campos et al. 2001; Ribeiro et al. 2003), and heifers start milking at an average age of 26 months. The weight of the animals was considered according to each dairy farm studied. The lifetime adopted for the dairy cows was 6 years.

The $\mathrm{CH}_{4}$ from enteric fermentation was calculated according to tier 2 protocols from the IPCC guidelines (IPCC 2006a; b), with an exception made for the methane conversion factor $(\mathrm{Ym})$, for which we used the value of $5.4 \%$ according to Primavesi et al. (2012) for data applied to dairy farms from Brazil, we used data according to Brazilian Agricultural Research Corporation (Embrapa 2012). Primavesi et al. (2012) evaluated the account of original ruminal methane (emissions rates or emissions factor, $\mathrm{kg} \mathrm{cow}^{-1}$ year $^{-1}$ ) for cow breed Holstein on Brazilian production systems in pasture-based grazing system (summer and autumn), in order to obtain more accurate data. They considered $4.38 \mathrm{Mcal}$ of gross energy and $0.01334 \mathrm{Mcal} / \mathrm{g} \mathrm{CH}_{4}$ to estimate the methane conversion factor (Ym).

Live body weight, milk yield, and roughage feed data were collected by the manager of each dairy farm, and some information was adjusted according NRC (2001), Peripolli et al. (2011), Valadares Filho et al. (2011). The manure emissions were calculated according to the IPCC (2006a; b) based on the DMI with digestibility rates of $66.0,70.0$, and $69.0 \%$ for the confined feedlot, semi-confined feedlot, and pasture systems, respectively (NRC 2001; Peripolli et al. 2011; Valadares Filho et al. 2011).

The nitrogen in excreta was calculated as the total amount of $\mathrm{N}$ in the feed DMI minus the amount of $\mathrm{N}$ in milk and animals (calves and growth) for each dairy farm studied. The direct emissions of $\mathrm{N}_{2} \mathrm{O}$ from soil were calculated according to the IPCC (2006b), and the indirect emissions caused by volatilization of ammonia $\left(\mathrm{NH}_{3}\right)$ and leaching of nitrate $\left(\mathrm{NO}_{3}\right)$ were estimated using emission factor $(\mathrm{EF})$ values according to the IPCC (2006a). The $\mathrm{CO}_{2}$ emitted from enteric fermentation by dairy cattle was excluded from the study that of according IPCC (2007), this gas was considered neutral with respect to GHG emissions.

Data on grain production were modeled according to secondary data for soybean and corn (Alvarenga et al. 2012; Prudêncio da Silva et al. 2010; Prudêncio da Silva 2011) while for cottonseeds and barley, we used data from Ecoinvent ${ }^{\circledR}$ (Nemecek and Kägi 2007) due to lack of Brazilian data, modified to not consider $\mathrm{CO}_{2}$ absorption by grain. Data for barley processing were from Kløverpris et al. (2009) and Tumuluru et al. (2011).

\subsection{Variation of data-input and output of $\mathrm{N}$}

All the nutrient requirements of individual animals and whole herd were calculated using the Nutrient Requirements of Dairy Cattle (NRC 2001). The annual amount of feed intake was estimated separately for each farm analyzed and presented as feed intake (dry matter, gross energy, crude protein) per kilogram of fresh milk (NRC 2001). Animal diets were formulated to provide the feed requirements of the animals within each farm according to body weight, milk production, sex, and live weight gain (NRC 2001). The $\mathrm{N}$ content in the DMI in each system was calculated from the parameters of the protein content in the DMI according to Valadares Filho et al. (2011), and for protein converted to N, a factor of 6.25 was used according to NRC (2001). Other variables, such as dry matter intake digestibility (DMID), total digestible nutrients (TDN), and crude protein (CP), were calculated for each dairy system according to the NRC (2001), Peripolli et al. (2011) and Valadares Filho et al. (2011) and complemented by discussions with cow feed experts (see Table 1). These variables were chosen because, according to several authors (Beever and Doyle 2007; Flysjö et al. 2011b; Henriksson et al. 2011; Kristensen et al. 2011; Merino et al. 2011; Primavesi et al. 2012; Yan et al. 2011), the composition of feed, consumption, and ECM production are the main drivers of enteric $\mathrm{CH}_{4}$ emissions, along with energy utilization efficiency. The main differences among the systems in feed intake occur because the confined feedlot and semi-confined feedlot systems are using some by-products of other agricultural products in the animal diet.

\subsection{Life cycle impact assessment}

This study assessed only the CF of milk production, with the indicator presented in carbon dioxide equivalents $\left(\mathrm{CO}_{2} \mathrm{e}\right)$, as characterized by the Global Warming Potential (GWP) over a 100 -year time horizon considering that along with other gasses, $1 \mathrm{~kg}$ of $\mathrm{CH}_{4}$ has 25 times the GWP of $\mathrm{CO}_{2} \mathrm{e}$ (thus $1 \mathrm{~kg}$ of $\mathrm{CH}_{4}$ means $25 \mathrm{~kg} \mathrm{CO}_{2} \mathrm{e}$ ) and that $1 \mathrm{~kg}$ of $\mathrm{N}_{2} \mathrm{O}$ represents $298 \mathrm{~kg}$ of $\mathrm{CO}_{2} \mathrm{e}$ (IPCC 2007). According to Flysjö et al. (2012), there is not yet an international standardized method for calculating GHG emissions associated with milk products, but some guidelines have been developed. The ISO (2006a; b) was adopted in this paper.

\subsection{Monte Carlo analysis}

Because of the effects the diet of the cows in each system studied has on the GHG emissions, a sensitivity analysis was conducted on input data for total digestible nutrients (TDN) and crude protein $(\mathrm{CP})$ based on values from the literature (NCR 2001), which were reviewed and accepted by Brazilian experts in nutrition in dairy production (Peripolli et al. 2011; 
Valadares Filho et al. 2011) (see Table 1). Parameters used in the analysis were TDN and $\mathrm{CP}$ because they have a closeness interrelation with $\mathrm{CH}_{4}$ enteric and $\mathrm{N}_{2} \mathrm{O}$ manure (Table 3).

The results from this analysis were applied in a Monte Carlo (MC) simulation run independently for each dairy farm based on 10,000 iterations to analyze the uncertainty distribution in the GHG emissions. For the MC simulation, we used a minimum, mean and maximum data from three case studies.

\section{Results}

The comparative LCA showed that the confined feedlot system had a lower $\mathrm{CF}$ than the other two systems studied (see Table 2). GHG emissions were $0.535 \mathrm{~kg} \mathrm{CO}_{2} \mathrm{e} \mathrm{kg} \mathrm{ECM}^{-1}$ for the confined feedlot system, $0.778 \mathrm{~kg} \mathrm{CO}_{2} \mathrm{e} \mathrm{kg} \mathrm{ECM}^{-1}$ for the semi-confined feedlot system, and $0.738 \mathrm{~kg} \mathrm{CO}_{2} \mathrm{e} \mathrm{kg} \mathrm{ECM}^{-1}$ for the pasture-based system. When the direct land use change (dLUC) for grain and cottonseed production was considered, the $\mathrm{CF}$ increased by $45.0,36.9$, and $37.3 \%$ for the confined feedlot, semi-confined feedlot, and pasture-based systems, respectively. The results showed a higher increase in the CF for the pasture-based system, although the dLUC was expected to be more significant for the confined feedlot and semiconfined feedlot systems. This result occurred due to the higher use of soybean in pasture system, this grain has more environmental costs associated with deforestation since there is no land competition for this crop. In Brazil, the climate allows two crop cultivations per year, i.e., 6 months for the soybean crop (Prudêncio da Silva 2011) while for the successive crops, there is land competition for corn, barley, cotton, and other crops, so a factor of 0.7 is used in the calculation of these crops. The concentrated feed in the confined feedlot and semi-confined feedlot systems is cottonseed-and brewers spent grain-based, while the pasture-based concentrated feed is corn and soybean meal-based (Table 2).

Table 2 Carbon footprint of Brazilian dairy production (expressed as $\mathrm{kg}$ $\mathrm{CO}_{2} \mathrm{e} \mathrm{kg} \mathrm{ECM}{ }^{-1}$ )

\begin{tabular}{|c|c|c|c|}
\hline Life cycle steps & Confined feedlot & Semi-confined feedlot & Pasture \\
\hline Feed & 0.202 & 0.370 & 0.339 \\
\hline Transport & 0.003 & 0.004 & 0.002 \\
\hline Enteric fermentation & 0.280 & 0.287 & 0.369 \\
\hline Manure management & 0.042 & 0.106 & 0.024 \\
\hline Other activities ${ }^{\mathrm{a}}$ & 0.008 & 0.010 & 0.004 \\
\hline Total & 0.535 & 0.778 & 0.738 \\
\hline dLUC & 0.241 & 0.287 & 0.275 \\
\hline Total with dLUC & 0.776 & 1.065 & 1.013 \\
\hline
\end{tabular}

${ }^{a}$ Other activities including the electricity used on the farm for milking and lightning
As shown in Table 2 for confined feedlot and pasture-based systems, the major $\mathrm{CF}$ was from enteric fermentation. In the semi-confined feedlot system, feed was mainly responsible for the $\mathrm{CF}$ with $47.6 \%$ of the GHG emissions, while enteric fermentation represented $36.9 \%$. In the confined feedlot system, the contribution from feed production was less significant with $37.8 \%$, while $52.3 \%$ was from enteric $\mathrm{CH}_{4}$. For the pasture-based system, the feed was responsible for $45.9 \%$ of the GHG emissions, and $50.0 \%$ of the GHG emissions were from enteric fermentation.

The main contribution to the $\mathrm{CF}$ for feed production in the confined feedlot system was the concentrated feed (27.2\%). The use of brewers spent grain in the concentrated feed accounted for $0.032 \mathrm{~kg} \mathrm{CO}_{2} \mathrm{e} \mathrm{kg} \mathrm{ECM}^{-1}$. Cottonseed was also an important ingredient in terms of climate change with $5.5 \%$ of the total milk CF. The use of corn and its by-products (gluten) in the concentrated feed represented emissions of $0.028 \mathrm{~kg} \mathrm{CO}_{2} \mathrm{e} \mathrm{kg} \mathrm{ECM}^{-1}$. Soybean meal usage emitted $0.021 \mathrm{~kg} \mathrm{CO}_{2} \mathrm{e} \mathrm{kg} \mathrm{ECM}^{-1}$. Corn germ usage contributed $0.044 \mathrm{~kg} \mathrm{CO}_{2} \mathrm{e} \mathrm{kg} \mathrm{ECM}^{-1}$. The impacts of corn production in Southern Brazil are associated with the high use of urea as $\mathrm{N}$ fertilizer, as observed by Prudêncio da Silva (2011). Corn silage production was responsible for $0.002 \mathrm{~kg}$ $\mathrm{CO}_{2} \mathrm{e} \mathrm{kg} \mathrm{ECM}{ }^{-1}$.

In the semi-confined feedlot system, the second highest $\mathrm{CO}_{2} \mathrm{e}$ emission was associated with the use of brewers spent grain, which accounted for $34.7 \%$ of the total milk CF $\left(0.270 \mathrm{~kg} \mathrm{CO}_{2} \mathrm{e}\right)$. Higher impacts associated with this ingredient are partly explained due to the allocation procedure used (i.e., mass) in the barley processing. Corn silage had an impact of $0.014 \mathrm{~kg} \mathrm{CO}_{2} \mathrm{e} \mathrm{kg} \mathrm{ECM}^{-1}$, while other ingredients in the animal diet, such as cottonseed, soybean meal, citrus pulp, mineral premix, and corn by-products, had a contribution of less than $8.0 \%$ of the total $\mathrm{CF}$. Emissions from grazing were responsible for $0.011 \mathrm{~kg} \mathrm{CO}_{2} \mathrm{e} \mathrm{kg} \mathrm{ECM}^{-1}$.

When analyzing the pasture-based system, corn silage was the ingredient with the highest contribution to climate change, $0.158 \mathrm{~kg} \mathrm{CO}_{2} \mathrm{e} \mathrm{kg} \mathrm{ECM}{ }^{-1}$, while emissions from pasture production were $0.048 \mathrm{~kg} \mathrm{CO}_{2} \mathrm{e} \mathrm{kg} \mathrm{ECM}{ }^{-1}$. Grain cultivation in this system was responsible for $19.3 \%$ of the total milk CF due to the use of corn and soybean meal in the concentrated feed. Hay emissions were $0.008 \mathrm{~kg} \mathrm{CO}_{2} \mathrm{e} \mathrm{kg} \mathrm{ECM}^{-1}$. Impacts from corn silage and pasture in this scenario were mainly due to the use of swine manure as an organic fertilizer $(11.8 \%$ of total $\mathrm{CO}_{2} \mathrm{e} \mathrm{kg} \mathrm{ECM}{ }^{-1}$ ).

The contribution of transport (for the purchase of commercial feed and on-farm transport) to milk production was low for the three systems, $0.5 \%$ for the confined feedlot and semi-confined feedlot systems and $0.2 \%$ for the pasture system. Manure management represented $7.8 \%$ of the CF for the confined feedlot system, while in the semi-confined feedlot system, emissions from manure were more significant at $13.7 \%$. In the pasture-based system, manure is 
handled only in the milking stage; these emissions contributed $3.2 \%$.

The total $\mathrm{CH}_{4}$ emission in Brazilian dairy production was $55.0,51.0$, and $57.0 \%$ for the confined feedlot, semi-confined feedlot, and pasture systems, respectively. The main contribution to GHG emissions from $\mathrm{CH}_{4}$ in the confined feedlot system was the enteric fermentation of cows with $52.3 \%$, while in the pasture-based system, enteric $\mathrm{CH}_{4}$ represented $50.0 \%$ of the total $\mathrm{CO}_{2} \mathrm{e}$. For the semi-confined feedlot system, the contribution of enteric fermentation was slightly lower but also significant with $36.9 \%$. For heifers, a calculated value for enteric $\mathrm{CH}_{4}$ emissions was of $22.1 \mathrm{~kg} \mathrm{CH}_{4}$ head $^{-1}$ year $^{-1}$ to confined system, $26.27 \mathrm{~kg} \mathrm{CH}_{4}$ head $^{-1}$ year $^{-1}$ to semi-confined system, and $28.81 \mathrm{~kg} \mathrm{CH}_{4}$ head $^{-1}$ year $^{-1}$ to pasture system.

Several nutritional factors have been identified in literature which affect the rate of enteric $\mathrm{CH}_{4}$ production in dairy cattle, and the key factors are related to FCE (DMI and ECM) (Beever and Doyle 2007; Flysjö et al. 2011b; Henriksson et al. 2011; Martin et al. 2010; Merino et al. 2011). Similar to Swedish studies (Henriksson et al. 2011), it is difficult to estimate how much the FCE can be improved to reduce milk $\mathrm{CF}$ due to lack of reference data in Brazil.

The contribution of $\mathrm{CH}_{4}$ from manure management in semi-confined system was greater than that in the other systems with $11.5 \%$ of the total $\mathrm{CO}_{2} \mathrm{e}$. In the semi-confined feedlot system, manure in the milking stage is handled as liquid slurry in tanks with a longer storage period than the other systems, leading to higher methane emissions due to methanogenesis. The relative $\mathrm{CO}_{2}$ contributions were 23.0 and $24.0 \%$ to the $\mathrm{CF}$ of milk in the confined feedlot and semi-confined feedlot systems, respectively, and $27.0 \%$ in the pasture system (Fig. 3). The $\mathrm{CO}_{2}$ emissions were mostly from fossil fuel combustion. The $\mathrm{N}_{2} \mathrm{O}$ relative contribution was $22.0 \%$ in the confined feedlot system, $25.0 \%$ in the semiconfined feedlot system, and $16.0 \%$ in the pasture-based system.

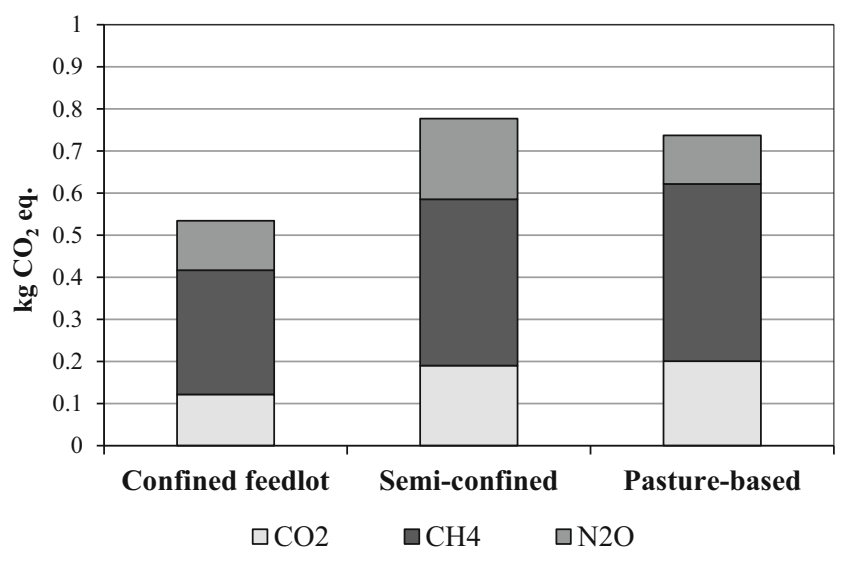

Fig. 3 Contribution of each GHG to the total CF

\subsection{Uncertainties}

Results from the MC simulation showed low uncertainty through variations in TDN and CP for the dairy farms studied. For the confined feedlot system, a mean value of $0.535 \mathrm{~kg}$ $\mathrm{CO}_{2} \mathrm{e} \mathrm{kg} \mathrm{ECM}{ }^{-1}$ and a standard deviation (SD) of 0.006 was observed. The coefficient of variation (CV) was low for the three systems evaluated, 1.1, 0.7 , and $1.0 \%$ for the confined feedlot, semi-confined feedlot, and pasture systems, respectively. In the semi-confined feedlot system, the mean value was $0.779 \mathrm{~kg} \mathrm{CO}_{2} \mathrm{e} \mathrm{kg} \mathrm{ECM}^{-1}$, while in the pasture system, the mean value was $0.738 \mathrm{~kg} \mathrm{CO}_{2} \mathrm{e} \mathrm{kg} \mathrm{ECM}^{-1}$. The SD was low for these two systems, similar to the confined feedlot system, with 0.005 for the semi-confined feedlot system, and 0.007 for the pasture system.

The effects of the DMI variation in animal diet on the enteric $\mathrm{CH}_{4}$ and $\mathrm{N}_{2} \mathrm{O}$ emissions from manure management can be observed in Table 3 . The uncertainties were due mainly to variations in $\mathrm{N}_{2} \mathrm{O}$ emissions from manure for the three systems. The $\mathrm{N}_{2} \mathrm{O}$ emissions had the greatest coefficient of variation $(\mathrm{CV})$ due to the variation in the DMI of the feed ingredients. The confined feedlot system showed the highest enteric $\mathrm{CH}_{4}\left(94.52 \mathrm{~kg} \mathrm{CH}_{4} \mathrm{cow}^{-1}\right.$ year $\left.{ }^{-1}\right)$, with the $\mathrm{N}_{2} \mathrm{O}$ emissions from the manure management at $0.752 \mathrm{~kg}$ $\mathrm{N}_{2} \mathrm{O}$ cow $^{-1}$ year $^{-1}$. Although the $\mathrm{CV}$ for these emissions was higher in the semi-confined feedlot system (Table 3), in the confined feedlot system, the $\mathrm{N}_{2} \mathrm{O}$ from manure was somewhat higher, which explains the greater $\mathrm{CV}$ in this system when the MC simulation was run for the CF for $1 \mathrm{~kg} \mathrm{ECM}$.

We did not consider the carbon sequestration by pastures and crops due to the lack of region-specific data in this study. However, some authors in Europe have considered carbon sequestration, and estimates were very uncertain due to the small amount of reliable data (Del Prado et al. 2013; Martin et al. 2010), which limits the improvement of the estimation of soil C dynamics (Del Prado et al. 2013). According to Soussana et al. (2009), grassland C sequestration has strong potential to partially mitigate the GHG balance of ruminant production systems and has shown satisfactory results in Europe. According to these authors, the mitigation of emissions and adaptation of livestock production systems to climate change will require a major international collaborative effort and long-term experiments to detect $\mathrm{C}$ stock changes.

\section{Discussion}

According to Zoccal et al. (2012), the milk production for most Brazilian farms (80.0 \%) is below $51 \mathrm{~kg} \mathrm{ECM} \mathrm{day}^{-1}$. Based on the results found in this study, it is therefore not possible to state that this CF $(0.535-0.778 \mathrm{~kg}$ $\mathrm{CO}_{2} \mathrm{e} \mathrm{kg} \mathrm{ECM}{ }^{-1}$ ) represents the entire Brazilian dairy 
Table 3 Parameters varied in the MC analysis to estimate the CF of Brazilian dairy farms

\begin{tabular}{|c|c|c|c|c|}
\hline Emissions & & Confined feedlot & Semi-confined feedlot & Pasture \\
\hline \multirow[t]{5}{*}{$\mathrm{CH}_{4}$, enteric $\left(\mathrm{kg} \mathrm{CH}_{4} \mathrm{cow}^{-1}\right.$ year $\left.^{-1}\right)$} & Min. & 91.74 & 89.78 & 81.50 \\
\hline & Mean & 94.52 & 92.09 & 83.61 \\
\hline & Max. & 97.59 & 94.52 & 85.73 \\
\hline & s.d. $^{\mathrm{a}}$ & 1.76 & 1.44 & 1.28 \\
\hline & $\mathrm{CV}(\%)^{\mathrm{b}}$ & 1.9 & 1.6 & 1.5 \\
\hline \multirow[t]{5}{*}{$\mathrm{N}_{2} \mathrm{O}$, manure $\left(\mathrm{kg} \mathrm{N}_{2} \mathrm{O}\right.$ cow $^{-1}$ year $\left.^{-1}\right)$} & Min. & 0.7094 & 0.3618 & 0.0507 \\
\hline & Mean & 0.7523 & 0.3961 & 0.0534 \\
\hline & Max. & 0.7988 & 0.4334 & 0.0562 \\
\hline & s.d. $^{\mathrm{a}}$ & 0.0271 & 0.0219 & 0.0016 \\
\hline & $\mathrm{CV}(\%)^{\mathrm{b}}$ & 3.6 & 5.5 & 2.9 \\
\hline
\end{tabular}

\footnotetext{
${ }^{\text {a }}$ Standard deviation

${ }^{\mathrm{b}}$ Coefficient of variation is the average variance of the mean value
}

production because these farms represent less than $3.0 \%$ of the dairy farms in Brazil that produce more than $202 \mathrm{~kg}$ ECM day ${ }^{-1}$. However, the results demonstrated that the reduction of GHG emissions is possible.

Methane emissions had the highest contribution to climate change, with an average of $54.0 \%(51-57)$, while $\mathrm{N}_{2} \mathrm{O}$ contributed an average of $21.0 \%(16-25)$ and fossil $\mathrm{CO}_{2}$ contributed an average of $25.0 \%$ (23-27) for the three Brazilian systems evaluated. Several authors (Basset-Mens et al. 2009a; Castanheira et al. 2010; Cederberg and Mattson 2000; Cederberg and Flysjö 2004; Flysjö et al. 2011a; Kristensen et al. 2011; Thomassen et al. 2008) obtained similar results when analyzing the contribution of each GHG to dairy production.

The results also showed that feed production and enteric fermentation are the major contributors to the total GHG emissions for the Brazilian dairy farms studied. Our results are in accordance with Flysjö et al. (2011a) for dairy farms in Sweden, with Bonesmo et al. (2013) for Norwegian farms, and with Basset-Mens et al. (2009a) for New Zealand farms and a little smaller than those for the pasture system in New Zealand from Flysjö et al. (2011a). $\mathrm{CH}_{4}$ emissions from ruminants represent a loss of productive energy for the animal. Thus, the development of feeding strategies (e.g., diet with higher quality and digestibility and supplements that improve rumen microbial activity) to mitigate these $\mathrm{CH}_{4}$ emissions may produce not only environmental benefits but also nutritional benefits for the animal (Martin et al. 2008).

The feed production emitted $0.200,0.370$, and $0.340 \mathrm{~kg}$ $\mathrm{CO}_{2} \mathrm{e} \mathrm{kg} \mathrm{ECM}{ }^{-1}$ (without considering the dLUC) in the confined feedlot, semi-confined feedlot, and pasture systems, respectively. These results are very similar to those in the study performed by Flysjö et al. (2011a) for dairy farms in Sweden, in which the feed is mechanically harvested and processed in Swedish milk production (approximately $0.390 \mathrm{~kg} \mathrm{CO}_{2} \mathrm{e} \mathrm{kg} \mathrm{ECM}^{-1}$ ), while in the New Zealand system, the feed emissions and relative contribution were the lowest (approximately $0.160 \mathrm{~kg} \mathrm{CO}_{2} \mathrm{e} \mathrm{kg} \mathrm{ECM}^{-1}$ ). In the New Zealand system, the feed intake is mostly by grazing. In our study, although a significant part of the animal diet is through grazing in the pasture system, we found the highest emissions due to the use of corn in silage and swine manure as an organic fertilizer. In the work of Castanheira et al. (2010), the contribution of the production of concentrates, corn, and ryegrass silage in dairy production in Portugal was somewhat lower, representing approximately $27.0 \%(0.280 \mathrm{~kg}$ $\mathrm{CO}_{2} \mathrm{e} \mathrm{kg} \mathrm{ECM}{ }^{-1}$ ) of the total global warming potential. The pasture and feed production in milk production in New Zealand was $0.390 \mathrm{~kg} \mathrm{CO}_{2} \mathrm{e} \mathrm{kg} \mathrm{ECM}{ }^{-1}$ (Basset-Mens et al. 2009a). For Norwegian farms, feed production had an emission of approximately $0.450 \mathrm{~kg} \mathrm{CO}_{2} \mathrm{e} \mathrm{kg} \mathrm{ECM}{ }^{-1}$ (Bonesmo et al. 2013). In a LCA of two dairy production systems in the Netherlands, Thomassen et al. (2008) showed that concentrated feed and roughage had a contribution to climate change ranging from 33.0 to $43.0 \%$. The impacts from concentrated feed in the three Brazilian systems were mainly due to $\mathrm{N}_{2} \mathrm{O}$ emissions from the nitrogen cycle from the use of chemical fertilizer and due to fossil $\mathrm{CO}_{2}$ from harvest and transport in grain production and from the production of chemical fertilizers.

The $\mathrm{CF}$ for the three Brazilian systems was lower than most of the results found in the literature (see Table 4). The most approximate results (Basset-Mens et al. 2009a; Cederberg and Mattson 2000; Cederberg and Flysjö 2004; Del Prado et al. 2013; González-Garcia et al. 2013; Rotz et al. 2010) showed a variation between 0.53 and $1.10 \mathrm{~kg} \mathrm{CO}_{2} \mathrm{e} \mathrm{kg}^{-1}$ ECM. However, according to González-Garcia et al. (2013), the differences in agricultural management regimes and other factors could explain the CF differences between studies.

We did not consider the dLUC in grain production, which can partly explain the lowest CFs in the three Brazilian systems in this study compared with the results from the 
Table 4 Comparative $\mathrm{CO}_{2} \mathrm{e} \mathrm{kg} \mathrm{ECM}{ }^{-1}$ for different studies

\begin{tabular}{|c|c|c|c|}
\hline Authors & Country & System & $\mathrm{kg} \mathrm{CO}_{2} \mathrm{e} \mathrm{kg} \mathrm{ECM}^{-1}$ \\
\hline \multirow[t]{3}{*}{ This study } & \multirow[t]{3}{*}{ Brazil } & Confined feedlot & $0.54^{\mathrm{a}} / 0.78^{\mathrm{b}}$ \\
\hline & & Semi-confined feedlot & $0.78^{\mathrm{a}} / 1.06^{\mathrm{b}}$ \\
\hline & & Pasture & $0.74^{\mathrm{a}} / 1.01^{\mathrm{b}}$ \\
\hline Basset-Mens et al. (2009b) & New Zealand & Conventional & 0.93 \\
\hline Bonesmo et al. (2013) & Norway & Conventional & 1.02 \\
\hline \multirow[t]{2}{*}{ Cederberg and Mattson (2000) } & \multirow[t]{2}{*}{ Sweden } & Conventional & 1.10 \\
\hline & & Organic & 0.90 \\
\hline \multirow[t]{3}{*}{ Cederberg and Flysjö (2004) } & \multirow[t]{3}{*}{ Sweden } & Conv. (High) & 0.90 \\
\hline & & Conv. (Med) & 1.04 \\
\hline & & Organic & 0.94 \\
\hline Castanheira et al. (2010) & Portugal & Conventional & 1.02 \\
\hline Del Prado et al. (2013) & Spain & Conventional & $1.2^{\mathrm{c}}$ \\
\hline \multirow[t]{2}{*}{ Flysjö et al. (2011a) } & Sweden & - & 1.16 \\
\hline & New Zealand & - & 1.00 \\
\hline \multirow[t]{2}{*}{ Flysjö et al. (2012) } & \multirow[t]{2}{*}{ Sweden } & Conventional & 1.07 \\
\hline & & Organic & 1.13 \\
\hline Gonzalez-Garcia et al. (2013) & Portugal & Conventional & 0.75 \\
\hline Henriksson et al. (2011) & Sweden & Conventional & 1.13 \\
\hline \multirow[t]{2}{*}{ Kristensen et al. (2011) } & \multirow[t]{2}{*}{ Denmark } & Conventional & 1.20 \\
\hline & & Organic & 1.27 \\
\hline Rotz et al. (2010) & USA & Conventional & 0.53 \\
\hline \multirow[t]{2}{*}{ Thomassen et al. (2008) } & \multirow[t]{2}{*}{ Netherlands } & Conventional & 1.41 \\
\hline & & Organic & 1.48 \\
\hline
\end{tabular}

${ }^{a}$ Without considering dLUC/

${ }^{\mathrm{b}}$ considering dLUC

${ }^{\mathrm{c}} \mathrm{kg} \mathrm{CO}_{2}$ e litre $\mathrm{ECM}^{-1}$

literature. If we considered the emissions for grain production and cottonseed, the CFs will increase to $0.78,1.06$, and $1.01 \mathrm{~kg} \mathrm{CO} \mathrm{e} \mathrm{kg}^{-1} \mathrm{ECM}$ for the confined feedlot, semiconfined feedlot, and pasture systems, respectively. Another parameter that can explain the low values from our systems is the FCE for the farms studied: $1.2 \mathrm{~kg} \mathrm{ECM} \mathrm{kg} \mathrm{DMI}^{-1}$ for the confined feedlot system and 1.3 and $1.1 \mathrm{~kg} \mathrm{ECM} \mathrm{kg} \mathrm{DMI}^{-1}$ for the semi-confined feedlot and pasture systems, respectively. In Flysjö et al. (2011a), the FCE was 1.0 and $0.9 \mathrm{~kg}$ ECM kg DMI ${ }^{-1}$ for Sweden and New Zealand, respectively. The FCE for Danish farms was 1.2 and $1.1 \mathrm{~kg} \mathrm{ECM} \mathrm{kg} \mathrm{DMI}^{-1}$ for conventional and organic (Kristensen et al. 2011), while the FCE for Portugal (Castanheira et al. 2010) and New Zealand (Basset-Mens et al. 2009a) was 1.0 and $0.7 \mathrm{~kg}$ $\mathrm{ECM} \mathrm{kg} \mathrm{DMI}^{-1}$, respectively. According to several authors (Beever and Doyle 2007; Flysjö et al. 2011b; Henriksson et al. 2011), FCE is a key indicator to reducing the GHG emissions because the feed intake is one of the most important production parameters in dairy production with an obvious risk of data uncertainty. Selection for milk yield or weight gain, and thus intensification of production, could result in lower $\mathrm{CH}_{4}$ production per kilogram of product, although daily emissions per animal increase (Martin et al. 2010). According to Martin et al. (2010), using today's current calculation practices, an increase in cow productivity results in a decrease in $\mathrm{CH}_{4}$ emissions per kilogram milk due to cow nutrition in actual dairy systems.

The EF for enteric fermentation was another parameter that showed great differences when comparing the systems (see Table 5). In this study, the estimation of enteric $\mathrm{CH}_{4}$ was based on gross energy intake, which can partly explain the differences because this estimate is directly influenced by the animal diet. Comparison of the various studies emphasizes the effect of each production system and variation in efficiency on the estimated environmental impact. In addition, a variation in the quality of feed expressed in the variability of TDN and CP can change the GHG results, as well as quality and composition of the feed given to the animals and the conversion factor (Ym) used for data applied to Brazil (of $5.4 \%$, based on Primavesi et al. (2012)). According to Del Prado et al. (2013), González-Garcia et al. (2013), and Primavesi et al. (2012), the emission factors of $\mathrm{CH}_{4}$ vary with the animal 
Table 5 Comparative enteric $\mathrm{CH}_{4}$ for different studies

\begin{tabular}{lll}
\hline Authors & Country (system) & $\begin{array}{l}\text { Enteric } \mathrm{CH}_{4} \\
\left(\mathrm{~g} \mathrm{CH}_{4} \mathrm{~kg} \mathrm{ECM}^{-1}\right)\end{array}$ \\
\hline This study & Brazil (confined feedlot) & $12.71^{\mathrm{a}}$ \\
& Brazil (semi-confined feedlot) & $13.06^{\mathrm{a}}$ \\
& Brazil (pasture) & $16.77^{\mathrm{a}}$ \\
Basset-Mens & New Zealand & 25.98 \\
et al. (2009b) & & \\
Castanheira & Portugal & 27.90 \\
et al. (2010) & & \\
Cederberg and & Sweden (conv. high) & 19.40 \\
Flysjö (2004) & Sweden (organic) & 20.70 \\
Flysjö et al. & Sweden & 21.49 \\
$\quad$ (2011a) & New Zealand & 24.81 \\
Henriksson & Sweden & 20.36 \\
et al. (2011) & & \\
Kristensen & Denmark (conventional) & 20.24 \\
et al. (2011) & Denmark (organic) & 23.41 \\
\hline
\end{tabular}

${ }^{\mathrm{a}}$ The dry matter intake was estimated

production system and the characteristics of the animals. According to the same authors, other variables that can affect $\mathrm{CH}_{4}$ emissions are feed intake (dry matter, digestible dry matter, digestible organic matter), live body weight $(\mathrm{kg})$, average daily weight gain $\left(\mathrm{kg} \mathrm{day}^{-1}\right)$, feeding system (confinement, intensive and extensive grazing), milk production $\left(\mathrm{kg} \mathrm{day}^{-1}\right)$, and fat content $(\%)$.

When analyzing the $\mathrm{MC}$ simulation, this study showed low uncertainty in the results through the variation of the DMI. The variation for the confined feedlot system was 0.524 $0.547 \mathrm{~kg} \mathrm{CO}_{2} \mathrm{e} \mathrm{kg} \mathrm{ECM}^{-1}$ and for the semi-confined feedlot and pasture systems was $0.769-0.790$ and $0.725-0.753 \mathrm{~kg}$ $\mathrm{CO}_{2} \mathrm{e} \mathrm{kg} \mathrm{ECM}^{-1}$, respectively. In studies on the Swedish dairy farm industry developed by Henriksson et al. (2011), MC results showed large variations in the milk $\mathrm{CF}$ from 0.940 to $1.330 \mathrm{~kg} \mathrm{CO}_{2} \mathrm{e} \mathrm{kg} \mathrm{ECM}{ }^{-1}$ due to variations in the ECM produced, delivered share (share of the milk delivery), feed $\mathrm{DMI}_{\mathrm{ECM}}$ (e.g., $\mathrm{kg} \mathrm{DMI} \mathrm{kg} \mathrm{ECM}^{-1}$ produced to relate feed DMI to milk yield), $\mathrm{N}$ content in DMI, $\mathrm{EF} \mathrm{CH}_{4}, \mathrm{~N}$-fertilizer rate, and diesel usage on the farm. However, to estimate the consumption of concentrates is relatively possible as opposed to the intake of roughage, which is seldom weighed on dairy farms and can also be fed in free grazing, being difficult to accurately determine the amount of ingested roughage.

The Brazilian dairy systems studied had differences in the $\mathrm{CH}_{4}$ emissions, DMI, feed composition, management of manure, milk production, use of net or gross energy, and other areas. Investment in grassland improvement is an opportunity to reduce GHG emissions because the type of forage has a direct influence on enteric $\mathrm{CH}_{4}$ emissions in ruminants (Martin et al. 2010). However, it is important to highlight that there is a lack of methods that estimate the feed intake of grazing animals (Buddle et al. 2011). Grassland yields are often poorly documented by farmers and mostly not weighed, so the feed intake of grazing animals is most likely the most uncertain parameter when studying milk and beef production (Henriksson et al. 2011).

It is important to mention that this work was focused on the CF of milk production systems. The results of the farm studied could be different if we analyzed other environmental impact categories as well (e.g., acidification), or if the farms were located in other regions of Brazil (e.g., center-west).

\section{Conclusions}

We concluded that the confined feedlot system has better environmental performance for climate change than the semi-confined feedlot and pasture systems. The dairy farms studied in the southern region of Brazil have good technology, and each one has a specific management strategy, indicating that there is a range for the improvement of milk production aimed at reducing GHG emissions. Uncertainties in feed intake data, mainly in the intake of grazing animals and silage, and the variability of feed consumption may influence the CF calculation for milk.

Actions towards grassland improvement, silage quality, feed cultivation, feed digestibility, and genetic potential, as well as the correct estimates of the amount of feed consumption, can influence the results of emissions per kilogram of milk produced according to the variations in TDN and CP evaluated. Accurate farm records are therefore critical for estimating the contribution of milk production to global warming and other environmental impact categories in the LCA. The feed conversion efficiency can be a key factor in making the Brazilian milk production more effective.

In addition, the generalization of these conclusions to any other region of Brazil must consider the great heterogeneities in the country in terms of soil and climate conditions, natural and cultivated forages, animal breeds, management herd, biodiversity, and other aspects and disparity in a variety of local milk production systems. This study can support future LCA analysis dealing with milk production and other agriculture topics in Brazil taking into account the lowest data available. Furthermore, the current trends in terms of the number of publications and resources availability for research, suggest that the use of LCA to quantify the potential environmental impact of food products will be an area of intense development in the near future. Also, the characterization of the different studied systems as to their global warming potential can assist in public policy for milk production with less environmental impact.

Acknowledgments The authors thank the Brazilian Science and Technology National Council (CNPq) for financially supporting this research 
in announcement $\mathrm{MCT} / \mathrm{CNPq} / \mathrm{CT}$-Agronegócio/MAPA-SDC $\mathrm{N}^{\circ} 40$ / 2008 and scholarship (CNPq-Process 143311/2009-3) and the Coordination of Improvement of High Education Personnel for a doctoral "sandwich" scholarship (CAPES/Brazil-Process 2410-11-7). We would like to thank Christel Cederberg of the Department of Sustainable Food Production of the Swedish Institute for Food and Biotechnology (SIK/Sweden), Universidade Federal de Santa Catarina (UFSC/Brazil), and Guilherme Marcelo Zanghelini of the Enciclo Sustainable Solution. We would also like to thank the anonymous reviewer for the helpful suggestions and comments.

\section{References}

Alvarenga RAF, Prudêncio da Silva V, Soares SR (2012) Comparison of the ecological footprint and a life cycle impact assessment method for a case study on Brazilian broiler feed production. J Clean Prod 28:25-32

Bartl K, Gómez CA, Nemecek T (2011) Life cycle assessment of milk produced in two smallholder dairy systems in the highlands and the coast of Peru. J Clean Prod 19:1494-1505

Basset-Mens C, van der Werf HMG (2005) Scenario-based environmental assessment of farming systems: the case of pig production in France. Agric Ecosyst Environ 105:127-144

Basset-Mens C, Kelliher FM, Ledgard S, Cox N (2009a) Uncertainty of global warming potential for milk production on a New Zealand farm and implications for decision making. Int J Life Cycle Assess 14:630-638

Basset-Mens C, Ledgard S, Boyes M (2009b) Eco-efficiency of intensification scenarios for milk production in New Zealand. Ecol Econ 68:1615-1625

Beever DE, Doyle PT (2007) Feed conversion efficiency as a key determinant of dairy herd performance: a review. Aust J Exp Agric 47:645-657

Bonesmo H, Beauchemin KA, Harsta OM, Skjelv AO (2013) Greenhouse gas emission intensities of grass silage based dairy and beef production: a systems analysis of Norwegian farms. Livest Sci 152:239-252

Brasil (1986) Ministério da Agricultura- Abastecimento e Reforma Agrária. Normas Técnicas parágrafo Execuções do serviço de Controle Leiteiro bovídeos EM. Diário Oficial da União, Brasília, DF, 15 out, N.195, Seção 1:1532-1535

BSI - British Standard Institution, Department for Environment, Food and Rural Affairs, Carbon Trust (2008) PAS 2050:2008 - Specification for the assessment of life cycle greenhouse gas emissions of goods and services. London, UK

Buddle BM, Denis M, Attwood GT, Altermann E, Janssen PH, Ronimus $\mathrm{RS}$ et al (2011) Strategies to reduce methane emissions from farmed ruminants grazing on pasture. Vet J 188:11-17

Campos AT de, Ferreira A de M, Pires M de FA (2001) Composição do rebanho e sua influência na produção de leite. Embrapa Gado de Leite. Circular técnica n 3, 23p

Carvalho L de A, Novaes LP, Gomes AT, Miranda JEC de, Ribeiro ACCL (2003) Sistema de Produção de Leite (Zona da Mata Atlântica). Embrapa Gado de Leite. Sistemas de Produção. Online version. [cited 2012 Nov 8] Available from: http:// sistemasdeproducao.cntia.embrapa.br/FontesHTML/Leite/ LeiteZonadaMataAtlantica/index.htm

Castanheira ÉG, Dias AC, Arroja L, Amaro R (2010) The environmental performance of milk production on a typical Portuguese dairy farm. Agric Syst 103:498-507

Cederberg C, Flysjö A (2004) Life cycle inventory of 23 dairy farms in South Western Sweden. Report. Swedish Institute for Food and Biotechnology Report No.: 728
Cederberg C, Mattson B (2000) Life cycle assessment of milk production - a comparison of conventional and organic farming. J Clean Prod 8:49-60

Cederberg C, Persson MU, Neovius K, Molander S, Clift R (2011) Including carbon emissions from deforestation in the carbon footprint of Brazilian beef. Environ Sci Technol 45:1773-1779

Dalgaard R (2007) The environmental impact of pork production from a life cycle perspective [thesis]. Faculty of Agricultural Sciences, University of Aarhus and Department of Development and Planning, Aalborg University

Del Prado A, Mas K, Pardo G, Gallejones P (2013) Modelling the interactions between $\mathrm{C}$ and $\mathrm{N}$ farm balances and $\mathrm{GHG}$ emissions from confinement dairy farms in northern Spain. Sci Total Environ 465:156-165

Embrapa-Empresa Brasileira de Pesquisa Agropecuária/Brazilian Agricultural Research Corporation (2012) Estoques de carbono e emissões de gases de efeito estufa na agropecuária brasileira. In: Lima M, Boddey RM, Alves BJR, Machado PLO de A, Urquiaga S editors. Brasília, DF, Embrapa, 347 p

FAO-Food and Agriculture Organization of the United Nations (2013a) Climate-Smart Agriculture Sourcebook. 570 p. Available from: http://www.fao.org/docrep/018/i3325e/i3325e.pdf

FAO-Food and Agriculture Organization of the United Nations (2013b) FAO Statistical Yearbook-World Food and Agriculture. 307p. Available from: http://www.fao.org/docrep/018/i3107e/i3107e.pdf

FAO-Food and Agriculture Organization of the United Nations (2010) Greenhouse gas emissions from the dairy sector: a life cycle assessment. Report. Animal Production and Health Division [cited 2012 Apr]. Available from: http://www.fao.org/docrep/012/k7930e/ k7930e00.pdf

Flysjö A, Henriksson M, Cederberg C, Ledgard S, Englund J-E (2011a) The impact of various parameters on the carbon footprint of milk production in New Zealand and Sweden. Agric Syst 104:459-469

Flysjö A, Cederberg C, Henriksson M, Ledgard S (2011b) How does coproduct handling affect the carbon footprint of milk? Case study of milk production in New Zealand and Sweden. Int J Life Cycle Assess 16:420-430

Flysjö A, Cederberg C, Henriksson M, Ledgard L (2012) The interaction between milk and beef production and emissions from land use change e critical considerations in life cycle assessment and carbon footprint studies of milk. J Clean Prod 28:134-142

Frischknecht R, Tuchschmid M, Faist-Emmenegger M, Bauer C, Dones R (2007) Strommix und Stromnetz. Ecoinvent report n ${ }^{\circ}$, v2.0. Paul Scherrer Institut Villigen, Swiss Centre for Life Cycle Inventories. Duebendorf, Switzerland

Gerosa S, Skoet J (2012) Milk availability trends in production and demand and medium-term outlook. ESA Working paper No. 1201. Agricultural Development Economics Division-Food and Agriculture Organization of the United Nations Available from: www.fao.org/economic/esa

González-García S, Castanheira ÉG, Dias AC, Arroja L (2013) Using life cycle assessment methodology to assess UHT milk production in Portugal. Sci Total Environ 442:225-234

Guinée JB, Gorrée M, Heijungs R, Huppes G, Kleijn R, Koning Ade, Oers LV, Wegener SA, Suh S, Haes HAUde, Bruijn Hde, Duin RV, Huijbregts MAJ (2002) Handbook on life cycle assessment. Operational guide to the ISO standards. I: LCA in perspective. IIa: Guide. IIb: operational annex. III: scientific background. Kluwer Academic Publishers, ISBN 1-4020-02289, Dordrecht, $692 \mathrm{p}$

Henriksson M, Flysjö A, Cederberg C, Swensson C (2011) Variation in carbon footprint of milk due to management differences between Swedish dairy farms. Animal 5:1474-1484

IBGE-Instituto Brasileiro de Geografia e Estatística (The Brazilian Institute of Geography and Statistics) (2011) Quantidade de leite cru ou resfriado adquirido e industrializado pelo estabelecimento, 
segundo os meses - Brasil [cited 2012 Dec 4]. Available from: http://www.ibge.gov.br/home/estatistica/indicadores/agropecuaria/ producaoagropecuaria/abate-leite-couro-ovos_201104_2.shtm

IDF-International Dairy Federation (2009) Environmental/ecological impact of the dairy sector: literature review on dairy products for an inventory of key issues- list of environmental initiatives and influences on the dairy sector. Bulletin of International Dairy Federation. Report No.: 436

IDF-International Dairy Federation (2010a) The World Dairy Situation 2010. Bulletin of International Dairy Federation Report No.: 446

IDF-International Dairy Federation (2010b) A common carbon footprint approach for Dairy, The IDF Guide to Standard Lifecycle Assessment Methodology for the Dairy Sector. Bulletin of International Dairy Federation. Report No.: 445

IPCC-Intergovernmental Panel on Climate Change (2006a) Guidelines for National Greenhouse Gas Inventories. Volume 4 Agriculture, Forestry and Other land use, Emissions from Livestock and Manure Management (Chapter 10)

IPCC-Intergovernmental Panel on Climate Change (2006b) Guidelines for National Greenhouse Gas Inventories. Volume 4 Agriculture, forestry and other land use, $\mathrm{N}_{2} \mathrm{O}$ emissions from managed soils, and $\mathrm{CO}_{2}$ emissions from lime and urea application (Chapter 11)

IPCC-Intergovernmental Panel on Climate Change (2006c) Guidelines for National Greenhouse Gas Inventories. IPCC National Greenhouse Gas Inventories Programme. Eggleston HS, Buendia L, Miwa K, Ngara T and Tanabe K (eds). Published: IGES, Japan. Available from: http://www.ipcc-nggip.iges.or.jp/public/2006gl/vol4.html

IPCC-Intergovernmental Panel on Climate Change (2007) Climate change 2007: the physical science basis. In: Solomon S, Qin D, Manning M, Chen Z, Marquis M, Averyt KB, Tignor M, Miller HL, editors. Contribution of Working Group I to the Fourth Assessment Report of the Intergovernmental Panel on Climate Change Chapter 2. United Kingdom: Cambridge University Press [cited 2012 Nov 26]. Available from: http://www.ipcc.ch/ipccreports/ar4wg1.htm

Iribarren D, Hospido A, Moreira MT, Feijoo G (2011) Benchmarking environmental and operational parameters through eco-efficiency criteria for dairy farms. Sci Total Environ 409:1786-1798

ISO 14040 (2006) Environmental management-life cycle assessmentprinciples and framework. International Organization for Standardization, Geneva

ISO 14044 (2006) Environmental management-life cycle assessmentrequirements and guidelines. International Organization for Standardization, Geneva

ISO 14067 (2013) Greenhouse gases-carbon footprint of products-requirements and guidelines for quantification and communication. International Organization for Standardization, Geneva

Jungbluth N, Chudacoff M, Dauriat A, Dinkerl F, Doka G, Faist Emmenegger M, et al. (2007) Life cycle inventories of bioenergy. Ecoinvent report No. 17. Dübendorf (Switzerland): Swiss Centre for Life Cycle Inventories

Kløverpris JP, Elvig N, Nielsen PH, Nielsen AM, Ratzel O, Karl A (2009) Comparative life cycle assessment of malt-based beer and $100 \%$ barley beer. Novozymes A/S and Harboes Bryggeri. Available from: http://www.novozymes.com/en/sustainability/Published-LCAstudies/Pages/default.aspx

Knudsen MT, Yu-Hui Q, Yan L, Halberg N (2010) Environmental assessment of organic soybean (Glycine max.) imported from China to Denmark: a case study. J Clean Prod 18:1431-1439

Koeppen W (1948) Climatology a study of the climates land. Economic Culture Fund, Mexico

Kristensen T, Mogensen L, Knudsen MT, Hermansen JE (2011) Effect of production system and farming strategy on greenhouse gas emissions from commercial dairy farms in a life cycle approach. Livest Sci 140:136-148
Leip A, Weiss F, Wassenaar T, Perez I, Fellmann T, Loudjani P, et al. (2010) Evaluation of the livestock sector's contribution to the EU Greenhouse Gas Emissions (GGELS). Final report. European Commission, Joint Research Center, Ispra

Marques D (2003) Criação de Bovinos. 7th ed. Belo Horizonte: CVP Consultoria Veterinária e Publicações

Martin C, Rouel J, Jouany JP, Doreau M, Chilliard Y (2008) Methane output and diet digestibility in response to feeding dairy cows crude linseed, extruded linseed, or linseed oil. J Anim Sci 86:2642-2650

Martin C, Morgavi DP, Doreau M (2010) Methane mitigation in ruminants: from microbe to the farm scale. Animal 4:351-365

Massuda E M, Alves AF, Parré JL, Santos GT (2010) Panorama da cadeia produtiva do leite no Brasil. In: Santos GT dos, Massuda EM, Kazama DC da S, Jobim CC, Branco AF. Bovinocultura leiteira: bases zootécnicas, fisiológicas e de produção. Maringá: Eduem, p 9-25

Merino P, Ramirez-Fanlo E, Arriaga H, del Hierro O, Artetxe A, Viguria M (2011) Regional inventory of methane and nitrous oxide emission from ruminant livestock in the Basque Country. Anim Feed Sci Technol 166:628-640

NRC-National Research Council (2001) Nutrient requirements of dairy cattle. Subcommittee on Dairy Cattle Nutrition, Committe on Animal Nutrition, Board on Agriculture and Natural Resources, 7 th rev. ed., p 401

Nemecek T, Kägi T (2007) Life cycle inventories of Swiss and European agricultural systems. Final report Ecoinvent v2.0 No. 15a. Agroscope Reckenholz-Taenikon Research Station ART, Swiss Centre for Life Cycle Inventories, Zurich and Dübendorf, $\mathrm{CH}$. Available from: www.ecoinvent.ch

Nguyen TLT, Hermansen J, Mogensen L (2011) Environmental assessment of Danish pork. Report $n^{\circ} 103$, Department of AgroecologyAarhus University, Denmark. Available from: www.agrsci.au.dk

Notarnicola B, Hayashi K, Curran MA, Huisingh D (2012) Progress in working towards a more sustainable agri-food industry. J Clean Prod 28:1-8

Oliveira ED (2002) Opções de forrageiras de entressafra e inverno em sistema de integração lavoura e pecuária. In: Santos G, Branco A, Cecato U, Oliveira E, Parizotto ML editors. II Sul- Leite: Simpósio sobre Sustentabilidade da Pecuária Leiteira na Região Sul do Brasil. Maringá/ PR, p 189-205

Peripolli V, Prates ER, Barcellos JOJ, Neto JB (2011) Fecal nitrogen to estimate intake and digestibility in grazing ruminants. Anim Feed Sci Technol 163:170-176

Primavesi O, Berndt A, Lima MA de, Frighetto RTS, Demarchi JJA de A, Pedreira M dos S (2012) Produção de gases de efeito estufa em sistemas agropecuários: bases para inventário de emissão de metano por ruminantes. In: Lima MA, Boddey RM, Alves BJR, Machado P LO de A, Urquiaga $S$ editors. Estoques de carbono e emissões de gases de efeito estufa na agropecuária brasileira. Brasília, DF: Embrapa, p 239-70

Prudêncio da Silva V (2011) Effects of intensity and scale of production on environmental impacts of poultry meat production chains: Life cycle assessment of French and Brazilian poultry production scenarios [thesis]. Universidade Federal de Santa Catarina, Florianópolis, Brazil Available from: http://www.ciclodevida.ufsc. br/publicacoes.php

Prudêncio da Silva V, van der Werf HMG, Soares SR, Spies A (2010) Variability in environmental impacts of Brazilian soybean according to crop production and transport scenarios. J Environ Manag 91:1831-1839

Ribeiro AC, McAllister AJ, de Queiroz AS (2003) Efeito das taxas de descarte sobre medidas econômicas de vacas leiteiras em kentucky. Rev Bras Zootec 32:1737-1746

Rotz CA, Montes F, Chianese DS (2010) The carbon footprint of dairy production systems through partial life cycle assessment. J Dairy Sci 93:1266-1282 
Roy P, Daisuke N, Orikasa T, Xu Q, Okadome H, Nakamura N et al (2009) A review of life cycle assessment (LCA) on some food products. J Food Eng 90:1-10

Ruviaro CF, Gianezini M, Brandão FS, Winck CA, Dewes H (2012) Life cycle assessment in Brazilian agriculture facing worldwide trends. J Clean Prod 28:9-24

Sjaunja LO, Baevre L, Junkkarinen L, Pedersen J, Setãlä J (1990) A Nordic proposal for an energy corrected milk (ECM) formula. Proceedings of the 27th Bienal Session of the International Committee for Animal Recording (ICAR); 1990 July 2-6; Paris, France: EAAP Publication, pp 156-7

Soussana JF, Tallec T, Blanfort V (2009) Mitigating the greenhouse gas balance of ruminant production systems through carbon sequestration in grasslands. Animal 4:334-350

Spies A (2003) The sustainability of the pig and poultry industries in Santa Catarina, Brazil: a framework for change [thesis]. University of Queensland, Australia

Steinfeld H, Gerber P, Wassenaar T, Castel V, Rosales M, Haan C de (2006) Livestock's long shadow. Environmental issues and options. FAO, Food and Agriculture Organization of the United Nations, Rome

Stock LA, Carneiro AV (2010) Panorama do Leite online. Centro de Inteligência do Leite 2010; Year 4: No. 46. [cited 2011 Jul 1st]. Available from: http://www.cileite.com.br/content/estrutura-deprodu $\% \mathrm{C} 3 \% \mathrm{~A} 7 \% \mathrm{C} 3 \% \mathrm{~A} 30-$ de-leite-na-su $\% \mathrm{C} 3 \% \mathrm{~A} 9$ cia

Thomassen MA, van Calker KJ, Smits MCJ, Iepema GL, de Boer IJM (2008) Life cycle assessment of conventional and organic milk production in the Netherlands. Agric Syst 96:95-107
Thomassen MA, Dolman MA, van Calker KJ, de Boer IJM (2009) Relating life cycle assessment indicators to gross value added for Dutch dairy farms. Ecol Econ 68:2278-2284

Tumuluru JS, Wright CT, Hess JH, Kenney KL (2011) A review of biomass densification systems to develop uniform feedstock commodities for bioenergy application. Biofuels Bioprod Bioref 5:683-707

Valadares Filho SC, Machado PAS, Chizzotti ML, Amaral HF, Magalhães KA, Rocha Junior VR et al. (2011) CQBAL 3.0. Tabelas Brasileiras de Composição de Alimentos para Bovinos [cited 2011 Dec]. Available from: www.ufv.br/cqbal

Wiedmann T, Minx J (2008) A definition of carbon footprint. Ecological economics research trends. C. C. Pertsova, ed. Nova Science Publishers, Hauppauge, NY, pp 1-11

Williams AG, Audsley E, Sandars DL (2006) Determining the environmental burdens and resource use in the production of agricultural and horticultural commodities. Main Report. Defra Research Project IS0205. Bedford: Cranfield University and Defra. Available from: www.silsoe.cranfield.ac.uk/ www.defra.gov.uk

WRI WBCSD - World Resources Institute and the World Business Council for Sustainable Development (2011) The Greenhouse Gas Protocol - Initiative calculation tool -Available from: http://www. ghgprotocol.org/

Yan M-J, Humphreys J, Holden NM (2011) An evaluation of life cycle assessment of European milk production. J Environ Manag 92:372-379

Zoccal R, Alves ER, Gasques JG (2012) Diagnóstico da Pecuária de Leite nacional. Estudo Preliminar (Preliminar report): Contribuição para o Plano Pecuário 2012. Available from: http://www.cnpgl.embrapa.br/ nova/Plano_Pecuario_2012.pdf 